\title{
On the Renewal \\ of Economic Thinking
}

Welcome by the Editor-in-Chief

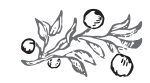

Journal of Economic Literature (JEL) codes: A11, E6, F11, F65, H6, O15, P41

Keywords: public finances, monetary policy, training in economics, London School of Economics, Hungary

History in Retrospection to the Period before the Crisis

Prior to the crisis that erupted in 2007-2008, there was a general consensus among the key economic policy theoreticians that financial regulation was not a macroeconomic instrument, and the mission of monetary policy called for the "single aim, single instrument", while doubts regarding the efficiency of fiscal policy became an entrenched pattern. In this approach, predilection to market participants' automaticity and the minimization of the state's role in economy organisation, control and regulation constituted the generally accepted pattern, and central banks operated as "islands" in the world of government finances.

Thus the most important goal expected of monetary policy was the stabilisation of inflation, at a low level, possibly around 2 per cent. The reason for this was that back then the stabilisation of inflation was believed to also stabilise the output gap, and the closed output gap was thought to ensure optimum GDP growth, also accepted for welfare considerations. However, it has been confirmed that if central banks only endeavour to stabilise inflation, economies end up in output gap bubbles, as seen, in the form of an overflow in lending, (first) in the Anglo-Saxon mortgage markets (in 2007). This, on the other hand, also destabilised inflation, in other words, in terms of inflation, tight inflation targeting proved to run counter to the intentions. Thus the lesson is that inflation must be stabilized but this cannot be the single objective of central banks.

Since then, the economic policy consensus implemented among the outlined framework conditions has also failed in practice. Crises can and do hit advanced mar- 


\section{On the Renewal of Economic Thinking - Welcome by the Editor-in-Chief}

ket economies, despite the fact that the leading economists had considered it inconceivable (Krugman, 1998), and not even the Japanese developments could get them thinking, as they reckoned with liquidity trap merely as a theoretical fiction. However, the liquidity trap did evolve and became reality, manifest in the form of market participant indebtedness and insufficient aggregated demand, and even the expected comprehensive economy boosting effects of negative real interest rates ${ }^{1}$ failed after some time. Thus, monetary policy hit a certain zero bottom, which was already insufficient for boosting the economy, and what is more, downturn and the threat of deflation evolved.

Unconventional monetary policy (Gertler and Karadi, 2011; 2013) targets bottlenecks and makes efforts at sending money where it is scarce. In other words, the aim is to prevent the liquidity trap caused by excessively plentiful money by re-channelling the funds of market participants with too much money to those who are struggling with cash flow problems. When nearly zero interest is paid, no loss is made on holding liquid assets, and therefore those with abundant liquidity rather tend to hold their money, however, this is not an optimum condition for the national economy.

In relation to monetary policy, it was confirmed that a genuine and credible inflation target is important, however, over the long term, stringent inflation targeting does not have a stabilizing effect. It became evident that after crises the neutral real interest rate may turn negative, and thus monetary policy shifts into a state of inertia. The very essence of unconventional monetary policy is that removal of liquidity traps requires non-conventional instruments.

Prior to the crisis, fiscal policy was also perceived differently. It was considered to have a delayed effect, as short-term downturns were presumed and thus its effects were thought to act already in the period of upturn, when they are no longer needed. Monetary policy alone is capable of overcoming short-term crises. Remembering J. M. Keynes's doctrines, it has been evidenced that the surplus earned from income increased by fiscal means (through wage increases and tax cuts) generates additional consumption at the level of households (in other words, wages and consumptions move roughly together), and so the aggregated demand will grow, and in turn, this will have its beneficial impacts felt in GDP growth and higher employment rates. During upturn wage growth does not fully generate consumption, however, during downturn, the impacts of current income growth appreciates, i.e. the effect of the budgetary multiplier on consumption is perceptible. This means that the current income (increased by fiscal means) does count (Eggertsson and Krugman, 2012) as during downturn the ratio of indebted consumers is high, and once they overcome indebtedness, they want to step higher on Maslow's pyramid of needs and turn several of their latent needs into effective (realisable) needs. Based on Keynes's recipe, in crisis management the fiscal multiplier's role is appreciated (Blanchard and Leigh, 2012; Auerbach and Gorodnichenko, 2012), although it is also true that in the upturn period, the counter-cyclical fiscal policy is reasonably pushed to the background, especially if matured automatic stabilisers are available. 


\section{Current Problems - \\ AND The Deficit in Theoretical Renewal}

The success of practical crisis management is beyond doubt. Both the previous hotbed of the crisis, the United States, and the European region ${ }^{2}$ have embarked on the course of consolidation. In the economies that have recovered by now brought crisis management to success through the revival of the Keynesian doctrine, giving precedence to the institutional approach, ${ }^{3}$ and assigning multiple mandates to the central bank. However, there is no comprehensive theoretical background underlying the economic policy practice and taught at school. One of the critical areas and most perceptible surfaces is higher education, and more specifically, training in economics. And this prevents the general appreciation of consolidation and the integration of the legislation drafted to manage the crisis. In other words, unless the syllabus of the pre-2007 period is replaced by the comprehensive new one in education, the applied economy management method cannot have theoretically support. Unless it is declared on a theoretical level that an economic policy excessively relying on market automaticity and an economic policy unreasonably displacing central regulation have harmful effects and cause crisis, and that inflation management is not the only role central banks have, genuine and full-fledged renewal is ruled out, and in particular, it is impossible to scientifically corroborate the new economic practice. Thus the achievements are easily annulled or at least their effects may taper off and become uninterpretable in certain layers of society. If public and business-based economy management is carried on with young economists trained according to the old theories, then the absence of theoretical revival may cause damages and discrepancies.

A peculiar attempt at solving this problem was the manifesto issued by economists at the London School of Economics to draw the attention to universal problems. Five hundred years after Martin Luther nailed his theses to the door of All Saints' Church in Wittenberg, the researches and students dissatisfied with the prevailing economic dogmas also nailed their 33 points on the entrance of the London School of Economics. In their opinion, the world is struggling with poverty, inequalities, an environmental crisis and financial instability, and they think economics could do more to help solve the problems. They are the first to mention that an unhealthy monopoly has evolved in economics. Education, research, policy consultation and public debates are all predominated by the neoclassical economic thought. Numerous other trends have been marginalised despite the fact that they could contribute useful advice to decision-makers. According to the authors of the proclamation, the debate should not be about which theory is better, rather we simply need debates, but there is none in economics. They disapprove that although neoclassical economics has yielded important historical results and remains useful to this day, it has not been improved, despite the fact that there are numerous opportunities to development, for example by establishing relations with other disciplines. Third, they criticize mainstream economics for its incapability of self-correction, and thus developing more as a religious argumentation than a scientific discipline. When theory and 
evidences come into conflict, evidences are disregarded far too frequently just to defend theories.

For this reason, the compilers of the manifesto invite the economists of the world for a debate. The manifesto implies that orthodox economics is on the point of operating in society nearly as a religious belief, and the "omniscient" priests of this science mystified with the help of complicated mathematics do not mingle with ordinary people while laying the basis for decisions affecting all through concealed value judgements.

\section{New Dogtrines from the Intellectual Gircles of the Catholic ChurGh}

In the midst of the labours of shaping new theoretical foundations, one of the pivotal phenomena is the economic philosophy expansion proposed by the intellectual circles of the Catholic Church. The basis of the pope's Encyclical Caritas in veritate published on St Peter's and St Paul's day was the global financial crisis. It proclaims that the economic growth driven by the exclusive principle of profit maximisation has caused dramatic problems that may be solved by cultural renewal and by laying the foundations of integrated, full-fledged human development. The social theory of the church includes an interdisciplinary approach that combines faith, metaphysics, theology and science. The encyclical points out that the ultimate objective of economic development is public happiness, and profit is only a means of achieving other, valuebased objectives. The fundamental principle of market operation is solidarity, mutual trust and moral, ethical and social responsibility. Companies and the members of the society come into contact with one another in the market, and therefore the state has a significant role in the operation of this central institution.

The warnings and scientific theories given by intellectual workshops linked to the Catholic Church provide a sound basis for reconsidering exclusivity, built on Adam Smith's teaching ${ }^{4}$ and having its effects felt to this very day, including the invocation of Antonio Genovesi, the classic author of the anthropocentric economics, after three hundred years of slumber and despite the fact that he was sidelined already by his contemporaries (Genovesi, 1765-1769). In economics, emphasis on anthropocentrism is for the most part ascribed to Ernst Schumacher and the 1970s, however, Genovesi wrote several centuries earlier that linking the economy with morals and the alignment of man with virtue was of primary significance among the economic axioms. The emphasis on bourgeois values, focus on values, a social approach, cooperation, public happiness and an ethics based on virtues are all important in the economy, and the concept advocated by Aristotle and St Thomas along with the Catholic Church's social teaching are very close to these ideas. The book by Luigino Bruni and Stefano Zamagni, who have adopted and carry forward Genovesi's intellectual heritage, is aimed at broadening the horizon after the crisis in thinking (Bruni and Zamagni, 2007). It main proposition is that the prosperity of social organisations seen in the past few decades was merely accidental, and they are no exceptions to the ordinary 
course of capitalist economic development, rather they represent a dire symptom of a crisis in the capitalist economy and also hope for a new start. They demonstrate that the operation of the globalised society and economy requires the re-discovery of the fundamental relationship between the "principle of contract" and the "principle of reciprocity". In their historical retrospection they confirm that market is "civilian" and has a "civilising" impact if and when it is characterised by reciprocity, and this is also the main message of the work by Genovesi, a Neapolitan priest and economist. Bruni and Zamagni think that a society that precludes the principle of reciprocity form its cultural horizon will become incapable of survival and of satisfying its members' demand for happiness. The keyword in their theory is happiness, defined more accurately and with a more relevant term, "public happiness", a category not falling in the least outside the scope of economic theory.

Clerical economic doctrines already include publications meant as manuals, like the book by Helen J. Alford O.P. and Michael J. Naughton (2001), and the academic activity of Dominican sister and economist Sarolta Laura Baritz O.P. as well as Professor Paul W. Dembinski’s new book certainly deserve mentioning.

Sister Laura's value creating work stems from the recognition that the principles of the Catholic Church's social teachings provide a suitable basis for an anthropocentric economics paradigm that differs from the mainstream, let us just call a spade a spade, the neoliberal economics based on objectives of unlimited profiteering. She is convinced that economics must not be practiced without morals, as ethics is a keystone of the economy, and a prerequisite of its sustainability. She believes that the right objective is not profit maximisation, it is only a partial goal. Instead of maximising profit at all costs, it should rather be optimised. The ultimate goal of the economy is what originally was: the implementation of the public good and the satisfaction of genuine needs. She glances back as far as the ancient times making references to Aristotle, Plato and Cicero down to St Thomas of Aquino, and arriving at our times, she integrates the prevailing ideas of the current heads of the Holy Mother Church about anthropocentric economy in her argumentation.

The continent of Europe could also benefit from placing the economy on a new footing, as our region has been losing ground to the global economy. The entire developed world, including the "West", is characterised by moderate economic growth, a significant loss in the population of the indigenous European nations, the abandonment of family ties and the refusal to undertake commitments, and Sister Sarolta Laura Baritz O.P. thinks the method applied so far offers no social or political solution or consensus for shaping the future, as the researchers of the London School of Economics also found wanting.

Paul Dembinski (2017) is of the opinion that we are witnessing the decline of "thirty euphoric years". The neoliberal method of production was undermined by subprime crisis that unfolded in the Anglo-Saxon mortgage markets from 2007, which was not primarily economic in nature, rather a failure in human self-control, which ruined millions of families, businesses, livelihoods and lives. Also in Hungary, in the decades preceding and following the millennium. After the 20th-century wars, the 
Great Depression and then the fall of communism, the most recent financial crisis, mankind is crying out for a new, equitable, humane, value-based and anthropocentric method of production and society.

Dembinski also describes new trajectories of action he offers as a compass. He surveys the extent to which the various participants of the financial system recognise the raison d'etre of ethical questions and the need of a solution. Dembinski thinks that the professional, accounting, legal and regulatory reasons for the crisis have been clarified, but the moral perspectives have been completely disregarded. Dembinski's objective is nothing else than to mark out the new paths of action at the level of cause and effect, in order to reconcile society with the real economy and the financial system.

\title{
The Hungarian Example - For and Against
}

In addition to the successful crisis management methods seen in the world and the broad desire for a theoretical renewal, mention must be made of the situation in Hungary. After the systemic crisis of the planned economy pursued for forty years, followed by two decades of a neoliberal economic transition with another systemic crises added at the end of the first decade of the 2000s, and on account of the successful economic consolidation that has been carried on for nearly a decade now, we Hungarians also feel the need for a theoretical renewal and its deficit in our education.

Successful and tuned fiscal and monetary crisis management, the enforcement of the budget multiplier, granting multiple mandates to the central bank, ${ }^{5}$ and the extension of the state's regulatory authority and ownership has been creating equilibrium in the budget as well as the foreign trade balance. Inflation is very slight and easy to moderate, and the beneficial effects of solvent demand and growth are manifest in wages and welfare benefits. ${ }^{6}$ However, no renewal has been instituted in terms of the comprehensive economic theory to underpin the economic practice. The transformation of economic education and filling the curriculum with new content remain tasks to be performed, and they may become the bottleneck in continuing the achievements.

Guided by the intention to remedy this deficiency, our journal undertakes to provide space for academic writings contributing to the intellectual renewal in Hungary and in the international space.

This is why it is worth reading the Polgári Szemle all over the world.

\author{
Professor Csaba Lentner, \\ Editor-in-Chief of Polgári Szemle
}




\section{Civic Review · Vol. 14, Special Issue, 2018}

\section{Notes}

1 In the year preceding the 2007 crisis in the United States real interest rates went into the negative, and this encouraged the propensity to borrow.

2 Apart, perhaps, from the Mediterranean.

3 Through the rediscovery of the works of Ronald Coase, Douglas North, John R. Commons, Walton Hamilton, Oliver Williamson and Dani Rodrik, etc. For a taxonomic framework of these doctrines, see Lentner, 2017. About the outdated and the new central banking system, see the same.

4 Its mainstream iconic figure is Adam Smith, author of The Wealth of Nations. One of his earlier works, The Theory of Moral Sentiments has points of similarity with the 18th-century Italian bourgeois economics. Moreover, the difference between his two books in terms of content is significant. However, posterity, and the liberalist paradigm only utilised The Wealth of Nations.

5 In addition to the moderation of inflation, the central bank's policy focuses on economic growth and financial equilibrium.

6 See the academic papers discussing the economic and social scheme in this journals issues for 2017 and 2018, https://eng.polgariszemle.hu/.

\section{REFERENGES}

Alford, Helen J. O.P. and Naughton, Michael (2001): Managing As If Faith Mattered: Christian Social Principles in the Modern Organization. University of Notre Dame Press, Notre Dame.

Auerbach, Alan J. and Gorodnichenko, Yuriy (2012): Measuring the Output Responses to Fiscal Policy. American Economic Journal: Economic Policy, Vol. 4, No. 2, pp. 1-27, https://doi.org/10.1257/pol.4.2.1.

Blanchard, Olivier and Leigh, Daniel (2012): Are We Underestimating Short-Term Fiscal Multipliers? World Economic Outlook, October, IMF, Washington.

Bruni, Luigino and Zamagni, Stefano (2007): Civil Economy: Efficiency, Equity, Public Happiness. Peter Lang AG, Bern.

Dembinski, Paul H. (2017): Ethics and Responsibility in Finance. Routledge, London and New York, https:// doi.org/10.4324/9781315205342.

Eggertsson, Gauti B. and Krugman, Paul (2012): Debt, Deleveraging and the Liquidity Trap: a FisherMinsky-Koo Approach. The Quarterly Journal of Economics, Vol. 127, No. 3, pp. 1469-1513, https://doi. org/10.1093/qje/qjs023.

Genovesi, Antonio (1765-1769): Lezioni di commercio o sia d'Economica civile.

Gertler, Mark and Karadi, Peter (2011): A Model of Unconventional Monetary Policy. Journal of Monetary Economics, Vol. 58, No. 1, pp. 17-34, https://doi.org/10.1016/j.jmoneco.2010.10.004.

Gertler, Mark and Karadi, Peter (2013): QE 1 vs. 2 vs. 3...: A Framework for Analyzing Large-Scale Asset Purchases as a Monetary Policy Tool. International Journal of Central Banking, January.

Krugman, Paul R. (1998): It's Baaack: Japan's : Japan's Slump and the Return of the Liquidity Trap. Brooking Papers on Economic Activity, Vol. 29, No. 2, pp. 137-206, https://doi.org/10.2307/2534694.

Lentner, Csaba (2017): New Concepts in Public Finance After the 2007-2008 Crisis. Economics E Working Capital, No. 1-4, pp. 2-8. 